\title{
Toplu Konutların İklimsel Konfor Tasarım Parametrelerine Göre Değerlendirilmesi: "Ilıman Nemli İklim Bölgesi: Edirne Binevler (1.Kısım) Konut Yapı Kooparetifi Örneği"
}

\author{
Filiz UMAROĞULLARI ${ }^{1 \star}$, Cenk CIHANGIR ${ }^{2}$
}

Öz

Türkiye'de yapı üretiminin büyük bir çoğunluğu toplu konutlardan oluşmaktadır. Bu nedenle sürdürülebilir bir çevre yaratmada toplu konut uygulamalarının önemi büyüktür. Genellikle alt ve orta gelir grubunun mülk sahibi olma beklentisini karşılamak amacıyla üretilen toplu konutlarda daha çok ilk yatırım maliyeti odaklı karar verilen, nitelikten çok nicelik öncelikli bir yaklaşım söz konusudur. Bu durum ekosistem ve sürdürülebilirlik açısından önemli problemlere neden olmaktadır. Problemlerin çözüm noktasında sürdürülebilir yaklaşımın temel adımlarından biri iklimle dengeli tasarımdır. Bu bağlamda, tasarımda en önemli girdilerden olan doğal ve yapay çevre verilerinin doğru değerlendirilerek alınacak kararların önemi büyüktür. Bu çalışmada, Türkiye'nin ılımannemli iklim bölgesinde bulunan Edirne Binevler (1. Kısım) Konut Yapı Kooperatifi iklimle dengeli tasarım parametreleri açısından değerlendirilmiştir. Günümüz toplu konut yaklaşımlarına göre kat sayısı, yeşil alan kullanımı vb. pek çok olumlu özelliğinin bulunmasına karşın konum, yön, form, kabuk ve yakın çevre ilişkisi açısından bazı parametrelerin iyi değerlendirilemediği görülmektedir. Sürdürülebilir ve nitelikli toplu konut uygulamalarının geliştirilmesine katkı sağlamak açısından enerji etkinliğine yönelik bölgesel farklılıkların dikkate alınarak iklimle dengeli tasarımların önemi ve gerekliliği vurgulanmak istenmiştir.

Anahtar Kelimeler: Iklim, iklimle dengeli tasarım, toplu konut, enerji verimliliği, yapı kabuğu

\section{Evaluation of Mass Houses According to Climatic Comfort Design Parameters: "Temperate Humid Climate Zone: Edirne Binevler (Part 1) Mass Housing Example"}

\begin{abstract}
\footnotetext{
${ }^{1}$ Trakya Üniversitesi, Mimarlık Fakültesi, Mimarlık Bölümü

2 Trakya Üniversitesi, Fen Bilimleri Enstitüsü, Mimarlık Anabilim Dalı

* İlgili yazar/Corresponding author: filizu@trakya.edu.tr

Gönderim Tarihi: 20.12.2019

Kabul Tarihi: 08.06.2020
}

A majority of the production structure in Turkey is composed of mass housing. Therefore, mass housing practices are important in creating a sustainable environment. Generally, mass housing produced in order to meet the expectation of ownership of the lower and middle income groups has a quantitative priority rather than a decision based on the initial investment cost. This causes important problems in terms of ecosystem and sustainability. One of the basic steps of the sustainable approach to the solution of problems is climate balanced design. In this context, the decisions to be taken by evaluating the natural and artificial environment data, which is one of the most important inputs in design, are of great importance. In this study, located in the 
temperate-humid climate of Turkey's Edirne Binevler (Part 1) Residential building cooperative is an example of balanced design parameters evaluated in terms of the climate. Although there are many positive features such as number of floors, green area usage, etc. according to today's mass housing approaches, some parameters cannot be evaluated well in terms of location, direction, form, shell and close environment relationship. In order to contribute to the development of sustainable and qualified mass housing applications, it is aimed to emphasize the importance and necessity of designing balanced with climate considering the regional differences in energy efficiency.

Keywords: Climate, climate balanced design, mass housing, energy efficiency, building envelope

\section{GíRiş}

II. Dünya Savaşı'ndan sonra küresel ısınma ve çevre sorunlarının hızla artması ile sürdürülebilir bir dünya yaratma düşüncesi tartışılmaya başlanmıştır. Bu doğrultuda sürdürülebilirlik, tüm çevre sorunlarına çözüm getirecek bir kavram olarak sunulmuştur (Onions, 1964). Sürdürülebilirlik, yapı için belirleyici bir kritertir ve doğaya saygılı, akılcı yaklaşımlar ile gelecek nesillerin yaşamlarını devam ettirebilmelerine olanak sağlamaktadır. Yapıların sürdürülebilir olarak tasarlanması, mimarlığın temel koşullarından biridir (Royal Jubilee Hospital Patient Care Centre Project, 2008; Sev, 2009). Bilindiği gibi enerji tüketiminin önemli bir bölümü binalardan kaynaklanmakta ve binaların kullanım süresince harcanan enerji, yaşam döngüsü boyunca kullanılan enerjinin \%65'ini oluşturmaktadır (Yeang, 2012). Bu durumda enerjinin etkin kullanılabilmesi iklimle dengeli tasarımlar sayesinde mümkün olacaktır.

Kişinin temel ihtiyaçlarından biri olan barınma gereksinimini karşılayan ve mevcut yapı stoğunun önemli bir bölümünü oluşturan konut yapıları da bu kapsamda öncelikli ele alınmalıdır. Hızlı sanayileşmeyle birlikte kırsal kesimlerden kentlere göç edilmesi hızlı ve ucuz konut intiyacını beraberinde getirmiştir. Başta İngiltere olmak üzere Avrupa'da çeşitli ülkelerde hızla gelişen ve çeşitlenen toplu konut örnekleri ortaya çıkmış, 20. yüzyılın başlarında ise toplu konutlar modernist yaklaşımlardan etkilenmişlerdir (Buğday, 1991). Tekil bir yapıda iklimsel parametrelerin değerlendirilmesi daha basit tasarım çözümleri sağlarken, toplu konutlarda her bir konut birimi için eşdeğer konfor sağlanması karmaşık çözümler gerektirmektedir.

\section{IKKLIMSEL KONFOR TASARIM PARAMETRELERI}

İklim, bir bölgede belirli zaman aralıklarında gözlemlenen hava olaylarının bölgeye etkilerinin uzun yıllara dayanan ortalamasıdır. İklimin oluşmasında sıcaklık, nem, rüzgâr, basınç ve yağışların ortak etkisi vardır. Dünya üzerinde konum ve topografik koşulların da etkisiyle sıcaklık ve nemlilik ortalamalarına göre sınıflandııılmış farklı iklim kuşakları bulunmaktadır. Yaygın olarak kullanılan Köppen'in iklim sınıflandırmasında aylık ortalama sıcaklık ve nemlilik verilerine göre oluşturulan iklim kuşakları beş ana grupta toplanmıştır. Bu iklim sınıfları; tropikal iklim, kuru iklim, ılıman iklim, karasal iklim ve soğuk iklimdir (Olgyay, 1962). Köppen'in iklim sınıflandırmasına göre Türkiye, ılıman iklim kuşağında bulunmaktadır (Erinç, 1996; Yılmaz \& Çiçek, 2016). Zeren (1978; 1987), Orhon (1988), Karaman (1995), Gürsel (1991) ve Akşit (2005) çalışmalarında, Türkiye iklim bölgeleri sıcak-nemli, sıcak-kuru, ılıman-nemli, ılıman-kuru ve soğuk olmak üzere beş iklim bölgesi olarak ele almışlardır. 
Güneş ışınım şiddeti, dış hava sıcaklığı, yağışlar, havanın nemi ve rüzgâr gibi iklimi oluşturan parametreler iklimsel konforu etkiler ve enerji korunumu sürecinde etkilidir. $\mathrm{Bu}$ doğrultuda iklimle dengeli tasarım, tasarımın yapılacağı bölgenin mikro iklimsel verileri dikkate alınarak yapılır. Bir mekândaki iklimsel konforun ek enerji sistemlerine en az intiyaç duyacak şekilde sağlanması için yapma çevreye ilişkin tasarım parametrelerinin uygun değerlerde olması gerekmektedir (Kun, 2005). Herhangi bir yapma çevredeki kullanıcının fiziksel ve zihinsel performansının istenen düzeyde olması ve sağlığının sürekliliği için en önemli gereksinmelerinden biri iklimsel konfor gereksinimleridir (Yıldız, 1989).

Yapılarda iklimsel konfor tasarım parametrelerinin optimum seviyede tutulması bir tasarım kararıdır. Bu karar, iklim unsurlarından en iyi şekilde yararlanmayı ve çevrenin olumsuz koşullarından yapıyı korumayı gerektirir. Tasarım kararları verilirken, bölgenin iklim koşulları, topografik yapısı, bitki örtüsü gibi doğal çevre verilerinin yanı sıra çevrede yer alan yapıların yakınlığı ve yüksekliğine bağlı olarak hava hareketlerinin yön ve şiddetinin değişebileceği, gölgeleme etkisi, yüzey kaplama malzemelerinin optik ve ısıl özelliklerinin de çok iyi analiz edilmesi gerekmektedir.

$\mathrm{Bu}$ çalışma kapsamında iklimle dengeli tasarımda, belirleyici olan parametreler yapı konumu, yapının yönlendirilmesi, yapı formu, yapı kabuğu ve yapının yakın çevresiyle yapılaşma düzeni olmak üzere 5 gruba ayrılmıştır.

\subsection{Yapının konumu}

Yapının arazi içerisindeki konumu, iklim şartlarının kontrol altına alınarak ısı kayıp ve kazançlarının azaltılmasında önemli bir etkiye sahiptir. Bir yapının yer seçiminde çevredeki diğer yapılar, bitki örtüsü, güneş ve rüzgârlar etkilidir. İlk aşamada doğal verileri oluşturan güneş ışınımları ve hava akımlarını dikkate alarak iklime göre topografik düzen içinde uygun yer seçimi yapılması gerekmektedir. Ayrıca, yapıların araziye yerleşiminde arazi formunu bozmadan, hafriyat veya dolgu gerekmeden mevcut eğime uygun konumlandırılması istenir (Tönük, 2001).

Ilıman iklimlerde güneşten ve rüzgârdan yararlanma ve korunma önemlidir. Bu sebeple ılıman kuru iklimlerde yamaçların alt kısımlarında, ılıman nemli iklimlerde ise yamaçların üst kısımlarına yerleşmek gerekmektedir (Şekil 1) (Zeren, 1978). Sıcak nemli iklim tiplerinde rüzgârın serinletici etkisinden yaralanabilmek için vadi sırtlarında konumlanmak uygundur. Sıcak kuru iklim bölgelerinde güneşin ısıtıcı etkisinden ve rüzgârın toz ve kum taşıma özelliğinden korunmak için vadiler tercih edilir. Soğuk iklim bölgelerinde güneşten optimum derecede yaralanabilmek ve rüzgarın olumsuz etkisinden korunmak için yamaçların güneye bakan yüzeylerinde, ısıl kuşağın aşağı kısımlarına yerleşilmelidir (Koçlar Oral, 2010). 


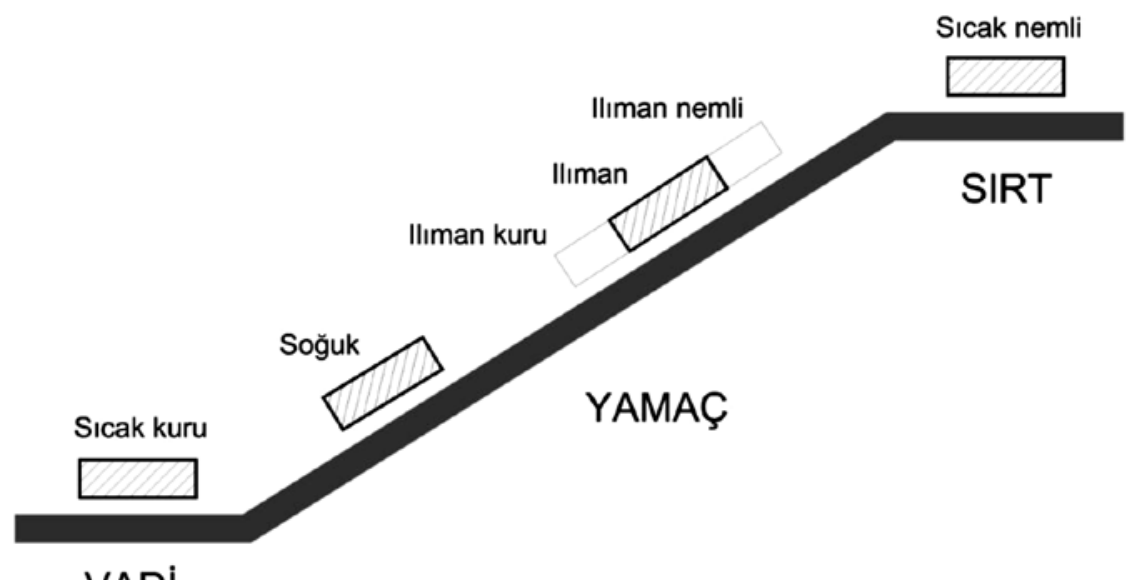

\section{VADi}

Şekil 1. İklim özelliklerine göre uygun topografik konumlar (Zeren, 1978)

\subsection{Yapının yönlendirilmesi}

Yeryüzünün farklı noktaları mevsimlere ve saatlere göre farklı yönlerde ve farklı şiddette güneş ışınımı etkisindedir. Yapının yönü gün ışığından faydalanma potansiyelinin yanı sıra ısı kayıp ve kazançlarını da değiştirmektedir. Bu nedenle yapı yönünün güney ile yaptığı açının bölgenin güneşlenme durumuna göre hesaplanması gerekmektedir. Yapının yönlendirilmesinde 2 temel unsur dikkate alınır; güneş kazancının kışın en yüksek, yazın ise en düşük düzeyde olmasını ve doğal havalandırma için hâkim rüzgâr etkisinden yararlanmayı sağlamaktır. Güneş ışınımının Isıtıcı ve rüzgârın ise serinletici etkisinden yararlanmada yön önemli bir rol oynamaktadır. Mevsimlere göre yeryüzünün farklı noktalarında, farklı yönlerden, farklı saatlerde, farklı şiddette güneş ışınımı alması, yapının yönlenmesine göre farklı aydınlatma olanağı ve ısı kazancı sağlanmasına neden olmaktadır. Bu nedenle optimum yönlenmenin güney ile yaptığı açı hakim rüzgar yönleri yapının yerine göre hesaplanarak saptanmalıdır (Evans, 1980; İnce ve Erdem, 2020).

\subsection{Yapının formu}

Yapı formu biçim faktörü, bina yüksekliği, çatı tipi, çatı ve cephe eğimi gibi geometrik değişkenlerin tümüdür. Binanın yatay ve düşey doğrultudaki boyutları, bina kabuğunun yüzey alanını belirler. Yapıların ısı kaybı/kazancı, yapının taban alanının yapı hacmine oranına (A/V oranı) bağlı olarak artar veya azalır (Evans, M., 1980). Aynı hacmi çevreleyen farklı biçimler için yapı dış yüzey alanı ve dış yüzeylerden kaybedilen ve kazanılan ısı miktarları da farklı olacaktır (Yılmaz, Koçlar Oral \& Manioğlu, 2000).

Yapı biçiminin belirlenmesinde o bölgenin iklimsel özellikleri oldukça etkilidir. Soğuk iklim bölgesindeki yapılar minimum ısı kaybı yaşanacak biçimde genellikle kompakt biçimler tercih edilerek tasarlanmalıdır. Tasarımda fazla hareketli dış konturlar yapı yüzeyinin gereksiz olarak büyümesine sebep olarak ısıtma enerjisini artırmaktadır.

Sıcak kuru iklim bölgesinde yapı fazla güneş ışınımlarından, rüzgârın kum ve toz taşıma etkisinden ve havanın kuruluğundan korunması gerekmektedir. Tasarımda güneş ışınımına maruz kalan alanı azaltmak için mümkün olduğunca kompakt kütleler tercih edilir. Kütleler iç içe geçecek şekilde planlanarak gölgeli alanlar elde edilmesi sağlanır ve avlular ile gölgeli ve serin mekânlar tasarlanır. Sıcak nemli iklim bölgesinde rüzgâra ve gölgeli alanlara intiyaç duyulur. Yapı, gölgelenme ve doğal havalandırma 
sağlanacak biçimde tasarlanır, rüzgârdan yararlanmak için yüzey alanı fazla, parçalı yapılar tercih edilir.

Ilıman nemli iklim bölgesinde yapıda soğuk dönemde minimum ısı kaybı sağlanmalı, güneş ışınımlarından en yüksek düzeyde yararlanılmalı, sıcak dönemde ise gölgelenme ve doğal havalandırma sağlanacak şekilde tasarlanmalıdır. Binalarda girinti ve çıkıntılar yazın gölgelenmeye, kışın ise güneş ışınımından en yüksek derecede yararlanmaya olanak sağlar. Yapılar genellikle dikdörtgen planlı, geniş cepheleri ise güney yönüne gelecek şekilde tasarlanır. Ilıman kuru iklim bölgesinde ise yapıda soğuk dönemde ısı kaybı minimuma indirilmeli, güneş ışınımlarından en yüksek düzeyde yararlanılmalı, sıcak dönemde ise gölgelenme sağlanacak şekilde tasarlanmalıdır. Yapılar form olarak ılıman nemli iklim ile benzerlik göstermektedir (Yılmaz vd., 2006, Evans, 1980).

\subsection{Yapı kabuğu}

Yapı kabuğu, binayı dış ortamdan ayıran yatay, düşey ve eğimli tüm yapı bileşenlerinin oluşturduğu yapı öğesidir (Akın, 2010). Saydam alanlar yapı kabuğunun ısı kayıp ve kazançlarında etkili olduğu için pencere yerleşimi ve doluluk boşluk oranları, güneşten yararlanma ve havalandırma açısından önemlidir. Kabuktaki saydam alanların artması, ısı geçişini artırırken, dolu alanların ısı yalıtımını etkisini azaltmaktadır. Ayrıca kabuğun ISı ve nem geçişine ilişkin güneş ışınımına karşı yutuculuk, geçirgenlik ve yansıtıcılık özellikleri, kabuğun eğimi, toplam ısı geçirme katsayısı, zaman geciktirmesi, genlik küçültme faktörü gibi özellikler etkilidir (Zorer, 1992). Kısmen düşük U değerine sahip kesitler ısı kazanç ve kaybını azaltmak açısından önemlidir (Evans, 1980).

Yapı kabuğu fiziksel özelliklerine bağlı olarak kabuk iç yüzey sıcaklıkları ısısal konforu da doğrudan etkilemektedir. Ayrıca yapının ısıtma, soğutma, aydınlatma enerjisi giderlerini belirlemede de çok etkilidir. Bu nedenle kabuk özellikleri doğru düşünülüp seçilmeli ve hem ısısal konfor hem de enerji korunumu sağlanmalıdır.

\subsection{Yapının yakın çevresiyle yapılaşma düzeniyle ilişkisi}

Yapılar, aralarındaki açık alan mesafelerine, yüksekliklerine ve konumlarına göre, güneş ışınımlarına ve rüzgâra karşı bariyer görevi üstlenmektedir. İklimsel özelliğe göre korunulması gereken ve faydalanılması gereken iklim elemanlarının öncelikleri belirlenerek doğru stratejiler kurulmalıdır. Yapıların, kent gibi yapılaşmanın yoğun olduğu bölgelere konumlanmasıyla, yapılaşmanın az olduğu kırsal alanlara konumlanması enerji etkin tasarım açısından önemli bir farklılık teşkil eder. Yapılaşmanın yoğun olduğu alanlarda hava hareket hızı daha az, hava sıcaklığı daha yüksek, hava kirlilik oranı daha fazla, artan hava kirliliği nedeniyle güneş ışınımı daha zayıf, azalmış bitki dokusuyla nem oranı daha düşüktür. Kentsel alanlardaki rüzgar hızı kırsal alanlardakine oranla \%25 daha az olmasına karşın yüksek yapıların arasında oluşan lokal kanyonlarda anormal rüzgar hızları oluşabilmektedir. Ayrıca yapıların yerleşim dokusu, ölçekleri ve birbirleriyle ilişkileri, caddeler, park gibi yeşil alanlar mikro klimayı doğrudan etkilediği göz önünde bulundurulmalıdır (Kun, 2005). Çizelge 1'de İklim tiplerine göre yararlanılması gereken iklimsel parametreler görülmektedir. Çalışma kapsamında örneklem seçilen toplu konut örneği ılıman nemli iklim iklimsel özelliği taşıyan Edirne ilinde yer almaktadır. 
Toplu Konutların İklimsel Konfor Tasarım Parametrelerine Göre Değerlendirilmesi: “Ilıman Nemli İklim Bölgesi: Edirne Binevler (1.Kısım) Konut Yapı Kooparetifi Örneği"

Evaluation of Mass Houses According to Climatic Comfort Design Parameters: "Temperate Humid Climate Zone: Edirne Binevler (Part 1) Mass Housing Example"

Çizelge 1. İklim tiplerine göre yararlanılacak parametreler

\begin{tabular}{|c|c|c|c|c|c|}
\hline ікLIM & \multicolumn{2}{|c|}{ SICAK İKLIM } & \multicolumn{2}{|c|}{ ILIMAN İKLİM } & \multirow[t]{2}{*}{ SOĞUK İLLIM } \\
\hline іKLIM & SICAK KURU & SICAK NEMLİ & ILIMAN KURU & ILIMAN NEMLII & \\
\hline $\begin{array}{c}\text { YAPI } \\
\text { KONUMU }\end{array}$ & Vadi & Vadi Sırt Kısımı & $\begin{array}{l}\text { Yamaç Alt } \\
\text { Kısımları }\end{array}$ & $\begin{array}{l}\text { Yamaç Üst } \\
\text { Kısımları }\end{array}$ & $\begin{array}{l}\text { Yamaç Alt } \\
\text { Kısımları }\end{array}$ \\
\hline $\begin{array}{l}\text { YAPININ } \\
\text { YÖNLENDIRI } \\
\text { LMESI }\end{array}$ & $\begin{array}{l}\text { Güneyden } 18^{\circ} \\
\text { Güneydoğu } \\
\text { Konumu }\end{array}$ & $\begin{array}{l}\text { Güneyden } 3^{\circ} \\
\text { Güneydoğu Veya } \\
\text { Kuzeye Bakan } \\
\text { Konum }\end{array}$ & $\begin{array}{l}\text { Güneyle } 12^{\circ} \text { Açı } \\
\text { Yapacak } \\
\text { Şekilde } \\
\text { Güneybatı İle } \\
\text { Kuzeydoğu } \\
\text { Aksında Konum }\end{array}$ & $\begin{array}{l}\text { Güneyden } 10^{\circ} \\
\text { Güneydoğuya } \\
\text { Bakan Konum }\end{array}$ & $\begin{array}{l}\text { Güneyden } 22^{\circ} \\
\text { Güneydoğuya } \\
\text { Bakan Konum }\end{array}$ \\
\hline YAPI FORMU & $\begin{array}{l}\text { •Avlulu, kompakt } \\
\text { form } \\
\text {-Yatayda yayılmış, } \\
\text { •Az katlı. } \\
\text {-Boyut; 1:1,3 oranı }\end{array}$ & $\begin{array}{l}\text { •Tek ve zeminden } \\
\text { yükseltilmiş, } \\
\text { •Hacimler arasında } \\
\text { boşluklar } \\
\text { oluşturulmuş } \\
\text { serbest düzende } \\
\text { uzun ve yüksek } \\
\text { form } \\
\text { •Boyut: } 1: 1,7 \text { veya } \\
\text { 1:1,3 oran }\end{array}$ & $\begin{array}{l}\text { •Kompakt form } \\
\text { •Boyut;1:1,1 } \\
\text { veya 1:1,3 oran }\end{array}$ & $\begin{array}{l}\text {-Serbest form } \\
\text {-Boyut; 1:1,6 } \\
\text { oran }\end{array}$ & $\begin{array}{l}\text {-Kompakt planlı, } \\
\text {-Boyut;1:1,1 veya } \\
\text { 1:1,3 oran }\end{array}$ \\
\hline $\begin{array}{c}\text { YAPI } \\
\text { KABUĞU }\end{array}$ & $\begin{array}{l}\text { •Cephe } \\
\text { yüzeylerinde } \\
\text { güneş ışınımına } \\
\text { karşı yutuculuğu } \\
\text { az, yansıtıcılığı } \\
\text { yüksek açık renk } \\
\text { kullanımı } \\
\text { •Sıcaklık etkisinin } \\
\text { azaltılması için } \\
\text { mekânların } \\
\text { cepheleri dar, } \\
\text { derinlikleri fazla } \\
\text { olmalıdır. } \\
\text { - Düz veya eğimli } \\
\text { vegölgelendirilmiş } \\
\text { çatılar, Çift yüzeyli } \\
\text { çatı } \\
\text { •Yapı kabuğunda } \\
\text { ısıtma önceliği } \\
\text { •lsı kazancını ve } \\
\text { ısı kaybını en aza } \\
\text { indiren ve ısı } \\
\text { depolama } \\
\text { kapasitesi yüksek } \\
\text { olan malzemeler } \\
\text { kullanılmalı }\end{array}$ & $\begin{array}{l}\text { •Cephe } \\
\text { yüzeylerinde } \\
\text { güneş ışınımına } \\
\text { karşı yutuculuğu } \\
\text { az, yansıtıcılığı } \\
\text { yüksek açık renk } \\
\text { kullanımı } \\
\text { - Düz veya eğimli } \\
\text { vegölgelendirilmiş } \\
\text { çatılar, Çift yüzeyli } \\
\text { çatı } \\
\text { •Yapı kabuğunda } \\
\text { soğutma önceliği } \\
\text { •İç bölgedeki ısı } \\
\text { konforunun en } \\
\text { düşük yapay enerji } \\
\text { ile sağlanabilmesi } \\
\text { için düşük ağırlıklı } \\
\text { ve yüksek yalıtımlı } \\
\text { malzemeler } \\
\text { kullanılmalı }\end{array}$ & $\begin{array}{l}\text { •Duvar ve çatıda } \\
\text { yalıtım } \\
\text { •Ek tasarım (kış } \\
\text { bahçesi vs.) } \\
\text { - Duvar } \\
\text { yüzeylerine orta } \\
\text { tonlu, çatı } \\
\text { yüzeylerinde } \\
\text { açık renkler } \\
\text { •Eğimli çatı, Tek } \\
\text { yüzeyli çatı, Çift } \\
\text { yüzeyli çatı } \\
\text { •Yapı kabuğunda } \\
\text { ısıtma önceliği } \\
\text { •Sıcak dönemde } \\
\text { ısı kazancını, } \\
\text { soğuk dönemde } \\
\text { ısı kayıplarını } \\
\text { azaltmak } \\
\text { amacıyla yapı } \\
\text { kabuğunun ısı } \\
\text { geçirgenlik } \\
\text { katsayısının } \\
\text { düşük olmalı }\end{array}$ & $\begin{array}{l}\text { •Duvar } \\
\text { yüzeylerine orta } \\
\text { tonlu, çatı } \\
\text { yüzeylerinde } \\
\text { açık renkler } \\
\text { •Eğimli veya düz } \\
\text { çatı, Tek yüzeyli } \\
\text { çatı, Çift yüzeyli } \\
\text { çatı } \\
\text { •Gölgeleme } \\
\text { elemanı } \\
\text { kullanımı } \\
\text { •Yapı } \\
\text { kabuğunda } \\
\text { ısıtma önceliği } \\
\text { •Sıcak dönemde } \\
\text { ısı kazancını, } \\
\text { soğuk dönemde } \\
\text { ısı kayıplarını } \\
\text { azaltmak } \\
\text { amacıyla yapı } \\
\text { kabuğunun ısı } \\
\text { geçirgenlik } \\
\text { katsayısının } \\
\text { düşük olmalı }\end{array}$ & $\begin{array}{l}\text {-Saydam yüzey } \\
\text { oranı azaltılmış, } \\
\text { küçük pencereli } \\
\text { yapı kabuğu } \\
\text { •Güneş alan } \\
\text { yüzeylerde orta, } \\
\text { almayan } \\
\text { yüzeylerde koyu } \\
\text { renkler } \\
\text { •Eğimli çatı, Tek } \\
\text { yüzeyli çatı } \\
\text { •Yapı kabuğunda } \\
\text { ısıtma önceliği } \\
\text { •lsı kaybını ve } \\
\text { yoğuşma } \\
\text { denetimini } \\
\text { sağlamak için ısı } \\
\text { geçirgenlik } \\
\text { katsayısı düşük } \\
\text { olacak şekilde } \\
\text { yapı kabuğu kesiti } \\
\text { oluşturulmalı }\end{array}$ \\
\hline $\begin{array}{c}\text { YAKIN } \\
\text { ÇEVRE } \\
\text { YAPILAŞMA } \\
\text { DÜZENI }\end{array}$ & $\begin{array}{l}\text {-Yapılar dış } \\
\text { ortama gölge } \\
\text { vermeli } \\
\text { •Gölgeli yaya } \\
\text { yolları } \\
\text { oluşturulmalı } \\
\text { •Işınım etkisini } \\
\text { azaltmak için yapı } \\
\text { yakın çevresinda } \\
\text { ya da avluda yeşil } \\
\text { doku kullanılmalı }\end{array}$ & $\begin{array}{l}\text { •Yapılar hava } \\
\text { akımı sağlayacak } \\
\text { şekilde dağınık ve } \\
\text { ayrık } \\
\text { konumlanmalı } \\
\text { •Yapının yakın } \\
\text { çevresi kısa ve } \\
\text { gölgeli olmalı }\end{array}$ & $\begin{array}{l}\text { •Yapı uzağında; } \\
\text { Hâkim rüzgâr } \\
\text { etkisini azaltmak } \\
\text { için yaprak } \\
\text { dökmeyen ağaç } \\
\text { kullanılmalı } \\
\text { •Yapı yakınında; } \\
\text { iğne yapraklu } \\
\text { bodur ağaçlar ve } \\
\text { sarmaşıklar } \\
\text { kullanılmalı }\end{array}$ & $\begin{array}{l}\text { •Sıcak } \\
\text { zamanlarda; } \\
\text { rüzgârı yapıya } \\
\text { yönlendirecek } \\
\text { soğuk } \\
\text { zamanlarda ise } \\
\text { yapıya rüzgârları } \\
\text { engelleyecek } \\
\text { şekilde yeşil } \\
\text { doku } \\
\text { tasarlanmalı } \\
\text { •Yapı yakınında } \\
\text { yaprak döken } \\
\text { ağaç ve çimen } \\
\text { kullanımı }\end{array}$ & $\begin{array}{l}\text { - Cadde ve } \\
\text { sokaklar } \\
\text { topografyaya } \\
\text { uygun } \\
\text { tasarlanmalı } \\
\text { •Binalardan } \\
\text { uzakta iğne } \\
\text { yapraklı ağaçlar, } \\
\text { bina yakınlarında } \\
\text { alçak gövdeli, } \\
\text { yaprak döken } \\
\text { ağaçların } \\
\text { kullanımı }\end{array}$ \\
\hline
\end{tabular}




\section{TOPLU KONUTLARDA IKLIMSEL TASARIM: EDIRNE BINEVLER (1.KISIM) YAPI KOPERATIFI ÖRNEĞI}

Türkiye'de tarihsel süreç içerisinde konut sorunu ve bu soruna bulunan çözümler, çeşitli dönemlerde değişik yaklaşımlar sergilenerek üzerinde durulan bir konu olmuştur. Ülkemizde kentleşme ve nüfus artışıyla ortaya çıkan konut sorunu başta büyük şehirler olmak üzere 1940'larda gündeme gelmiştir (Şenyapılı, 1985). 1950 yılından sonra sanayileşmenin de etkisiyle kentleşme hızı yükselmeye başlamış, kurumsal yapılar kentleşme hızının gerektirdiği konut intiyacını karşılamakta yetersiz kalmıştır. Konut ve kentleşme sorunlarına çözüm üretmek için, 1958 yılında İmar İskân Bakanlığı kurulmuştur. Yap-sat düzeni veya gecekondulaşmayla bu soruna çözüm bulunamayacağının anlaşıldığı 1960'lı yıllarda kooperatifler aracılığıyla toplu konut yapma fikri ortaya çıkmıştır. Konut sorunu her geçen gün büyüyen bir ivme kazanmış, 1970'li yıllarda da soruna çözüm olarak toplu konut türü sunum biçimleri ortaya çıkmaya başlamış, ancak bunlar kurumsallaşamadığı için konut kooperatifleri en önemli konut üreticisi durumuna gelmiştir. 1980'li yıllar Türkiye açısından bir geçiş dönemi olduğu için, sadece kentleşme anlamında değil, toplumsal yaşamın her alanında değişimin yaşandığı bir süreç olmuştur (İmamoğlu \& İmamoğlu, 1996).

Bu çalışma kapsamında 1970'li yıllarda görülen kooperatiflere örnek teşkil edecek özellikte Edirne Binevler (1.Kısım) Yapı Kooperatifleri örneklem olarak seçilmiştir. Edirne Cumhuriye Mahallesi konut yerleşmesi bu dönemde Edirne'de mevzi imar planı ile uygulanmış ilk toplu konut örnekleri arasındadır. Kentleşme hızı ve nüfus artışının neden olduğu konut ihtiyacı, etkisini tüm ülkede olduğu gibi Edirne'de de göstermiştir. Konut intiyacına çözüm bulmak amacıyla dönemin valisi Mustafa Karaer'in öncülüğünde 673 ortak bir araya gelerek Edirne Cumhuriye Mahallesi Sakinleri Yapı Kooperatifi'ni kurmuşlardır. Yer olarak, Arsa Ofisi tarafından tahsis edilen ve ek imar planında da gelişme alanı olarak öngörülen İstanbul yolu üzerinde yer alan ve Edirne'den $3 \mathrm{~km}$ uzaklıkta bulunan yeni istasyon yapısı karşısındaki arazi düşünülmüştür. 1978 sonunda başlanılan Edirne Cumhuriye Mahallesi 446 konutluk 1. Kısım, 1984 yılında iskâna hazır hale gelmiştir. Konutlar için kişiler, Emlak Kredi Bankası ve Sosyal Sigortalar Kurumu kredilerinden yararlanmışlardır. Ayrıca proje boyunca konut sahipleri tasarım sürecine dâhil edilmiştir (Varlı, 2017). (Şekil 2)

Site; 49 dönüm konut, bahçe ve 11 dönüm tescilli yeşil alan olmak 60 dönüm üzerinde yer alır. Sitede bulunan 446 konuttan 14 adedi dört katlı, 51 adedi üç katlı olmak üzere toplam 65 blok yer almaktadır (Varlı, 2017). (Şekil 3-4-5) 


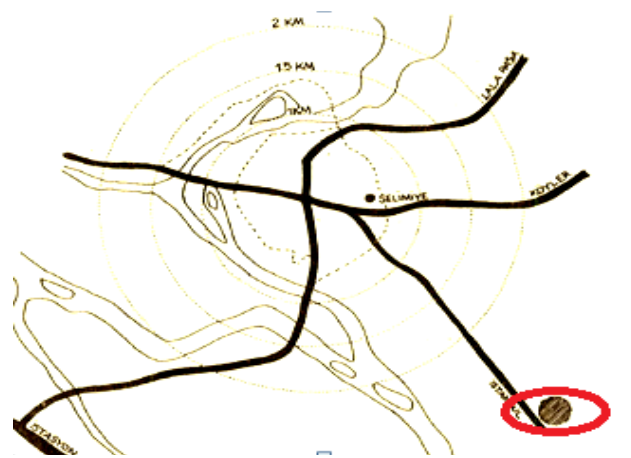

Şekil 2. Edirne Cumhuriye Mahallesi (Binevler) kentsel konumu (Bektaş, 1978) ve uydu görüntüsü

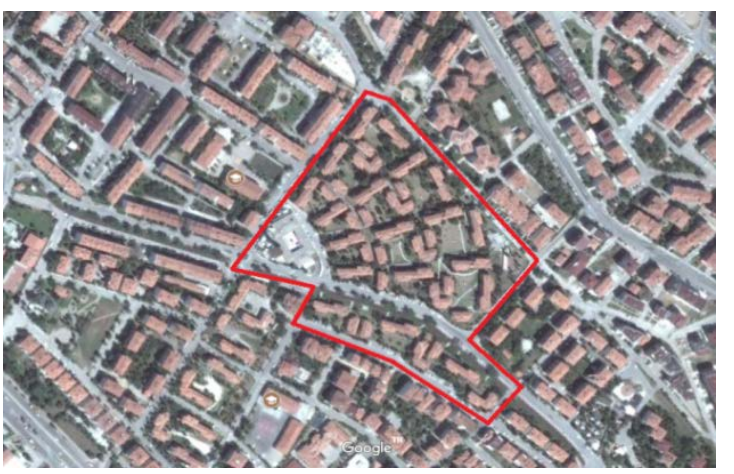

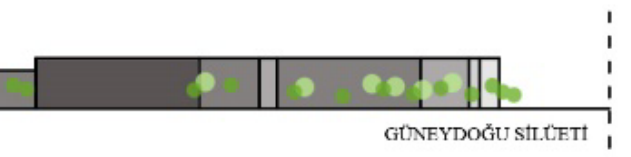

Şekil 3. Edirne Cumhuriye (Binevler) konut yerleşmesi silüeti
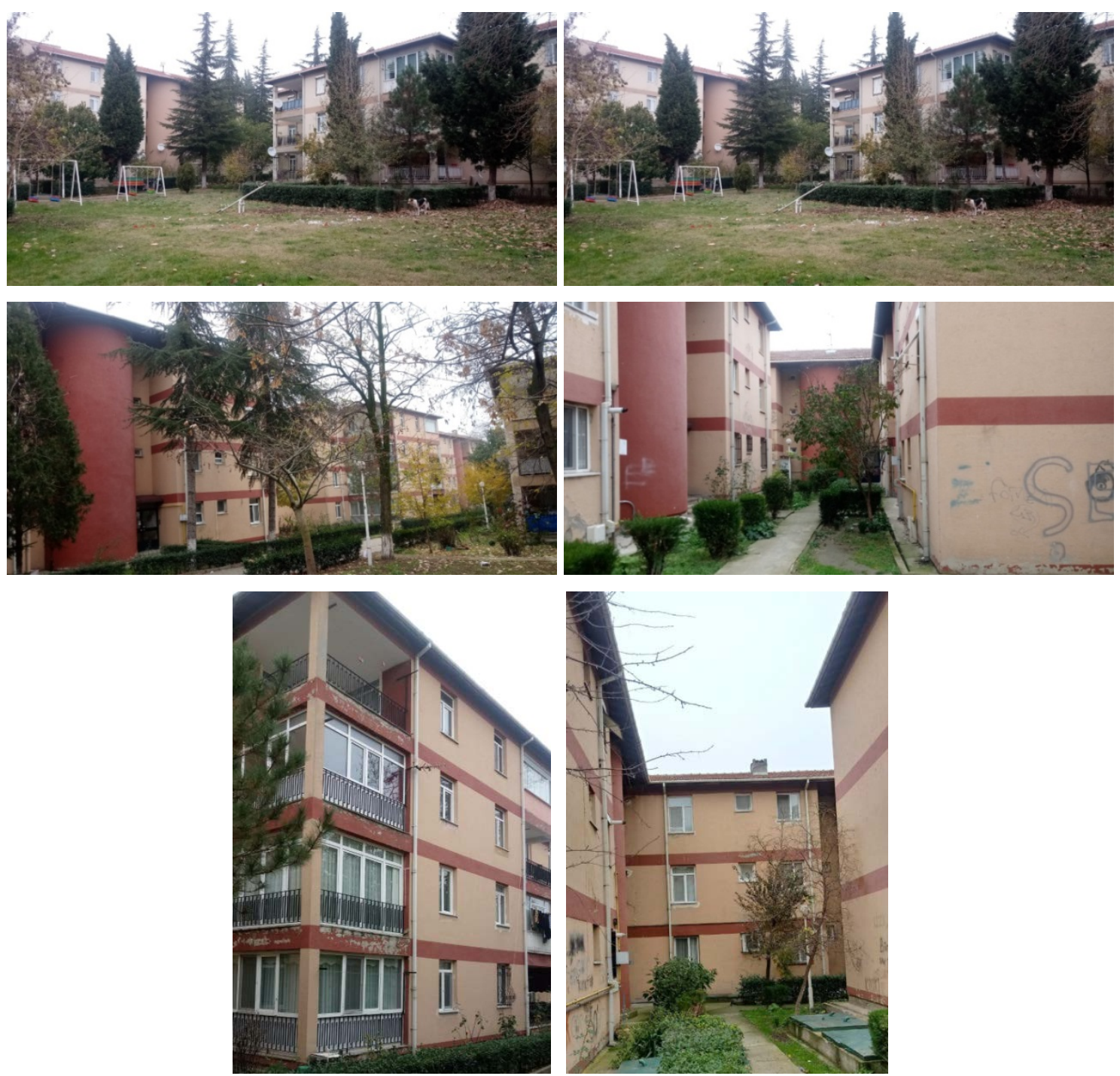

Şekil 4. Edirne Cumhuriye (Binevler) Konut Yerleşmesinden Görseller 


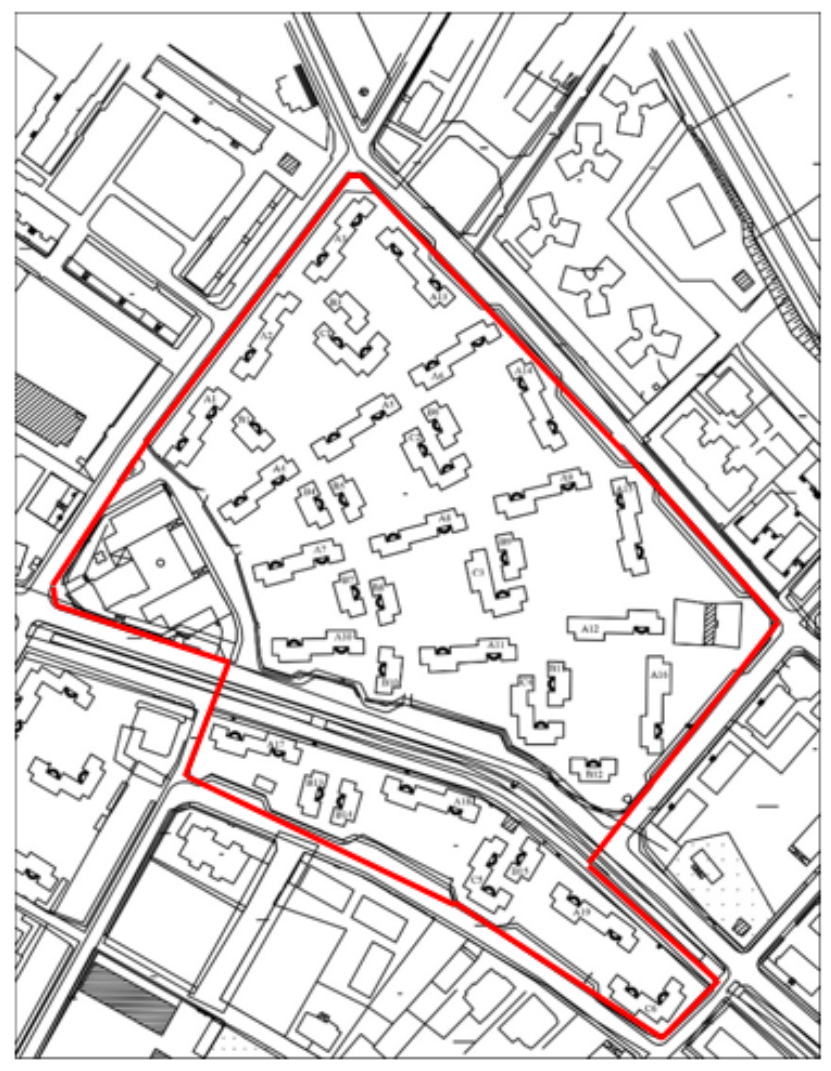

Şekil 5. Edirne Cumhuriye (Binevler) Konut Yerleşmesi Vaziyet Planı

Konutlar; 334 adedi 2+1, 112 adedi $3+1$ olmak üzere iki plan tipine sahiptir. $97 \mathrm{~m}^{2}$ brüt kullanım alanına sahip $2+1$ plan tipi olan konutlarda, yemek yeme ve oturma eylemlerinin gerçekleştiği bir salon, banyo+wc, wc ve mutfak bulunmaktadır. $109.56 \mathrm{~m}^{2}$ brüt kullanım alanına sahip 3+1 plan tipi olan konutlarda, farklı olarak sadece bir oda fazla bulunmaktadır (Varlı, 2017). (Şekil 6)

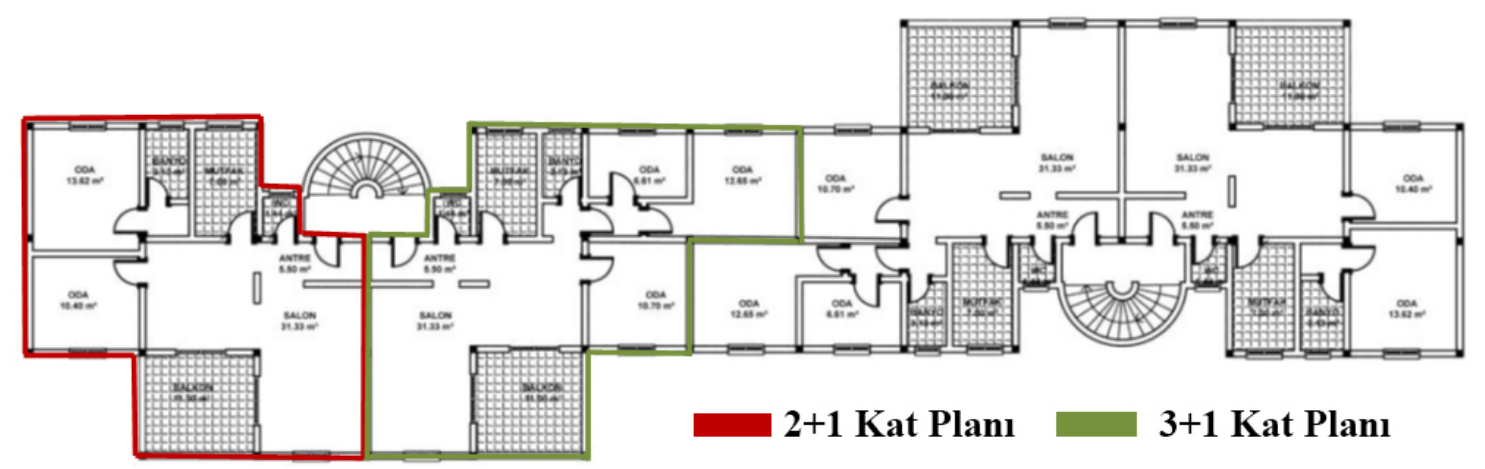

Şekil 6. Edirne Cumhuriye (Binevler) Konut Yerleşmesi Kat Planı

Yerleşimin merkezi konumunda tasarlanan çarşısı, Edirne kent merkezine giden ana arter üzerinde yer aldığı için, sadece siteye değil çevresine de hizmet veren bir duruma gelmiştir. Çarşı 36 dükkândan oluşmaktadır. Çarşının altında yer alan 1. bodrum katında 40 araç kapasiteli otopark, 2. bodrum katında sitenin ısıtma merkezi yer almaktadır (Varlı, 2017). 


\section{BULGULAR VE DEĞERLENDIRME}

Bu çalışmada, Edirne'nin ilk toplu konut projesi olan, Edirne Binevler (1. Kısım) Konut Kooperatifi örneği iklimsel konfor tasarım parametreleri açısından incelenmiştir. İncelenen toplu konut bloklarına ait değerlendirmeler tablolar halinde sunulmuştur.

KONUM: Trakya'nın batısında yer alan Edirne, geniş düzlük ve basık tepelerden meydana gelmektedir. Ilıman-nemli iklim bölgesinde uygun konum; güneydoğuya bakan yamaçların rüzgâr alabilecek üst bölümleri olmasına karşın Edirne'nin karakteristik özelliği nedeniyle Binevler Yapı Kooperatifi düzlük bir alanda konumlanmıştır.

YÖNLENME DURUMU: Literatürde optimum güneş yönlenmesi, güneyden $10^{\circ}$ güneydoğuya bakan konumlar olarak ifade edilmektedir. İyi yönlenme $13^{\circ}$ güneybatı $-35^{\circ}$ güneydoğu, geçerli yönlenmeler $23^{\circ}$ güneybatı- $49^{\circ}$ güneydoğu arasındadır (Orhon vd., 1988). Binevler yapı kooperatifinde üç farklı blok tipi bulunmaktadır. Her blok vaziyet planında farklı yönlenme durumları göstermektedir. Bu nedenle yönlenme durumları ayrı ayrı değerlendirilmiştir.

Çizelge 2. A Blok yönlenme durumunun değerlendirmesi

(1)

A blok birbirine zıt yönde iki farklı giriş olarak düzenlenmiş simetrik dikdörtgen bir plan şemasına sahiptir. Uzun kenarın güneyle yaptığı açı değerlendirildiğinde A1-A2-A3

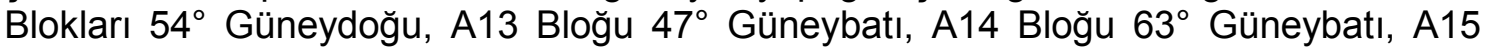


Bloğu $77^{\circ}$ Güneybatı, A16 Bloğu Doğu-Batı, A19 Bloğu ise $36^{\circ}$ Güneybatı yönünde konumlanmış olup kabul edilebilir yönlenme sınırları içerisinde olmadıkları görülmektedir. A4-A5-A6 Blokları 35 Güneydoğu, A7-A8-A9 Blokları 15 Güneydoğu, A10-A11-A12 Bloğu $3^{\circ}$ Güneydoğu, A17 Bloğu $16^{\circ}$ Güneybatı ve A18 Bloğu $20^{\circ}$ Güneybatı yönünde konumlanmıştır ve yönlenme durumları uygun kabul edilebilir. (Çizelge 2)

B blok tek girişli olarak düzenlenmiş simetrik dikdörtgen bir plan şemasına sahiptir. B1 Bloğu $47^{\circ}$ Güneybatı, B2-B3 Blokları $48^{\circ}$ Güneybatı, B4 Bloğu $65^{\circ}$ Güneybatı, B5-B6 Blokları $64^{\circ}$ Güneybatı, B7-B8-B9 Blokları $75^{\circ}$ Güneybatı, B10-B11 Blokları Doğu- Batı, B13 Bloğu $72^{\circ}$ Güneydoğu, B14 Bloğu 73 Güneydoğu, B15 Bloğu 58 ${ }^{\circ}$ Güneydoğu yönünde konumlanmıştır. $\mathrm{Bu}$ blokların yönlenmenin optimum değerlerini karşılayamadığı görülmektedir. Sadece B12 Bloğu güney yönünde konumlanmıştır ve uygun yönlenme durumu göstermektedir. (Çizelge 3)

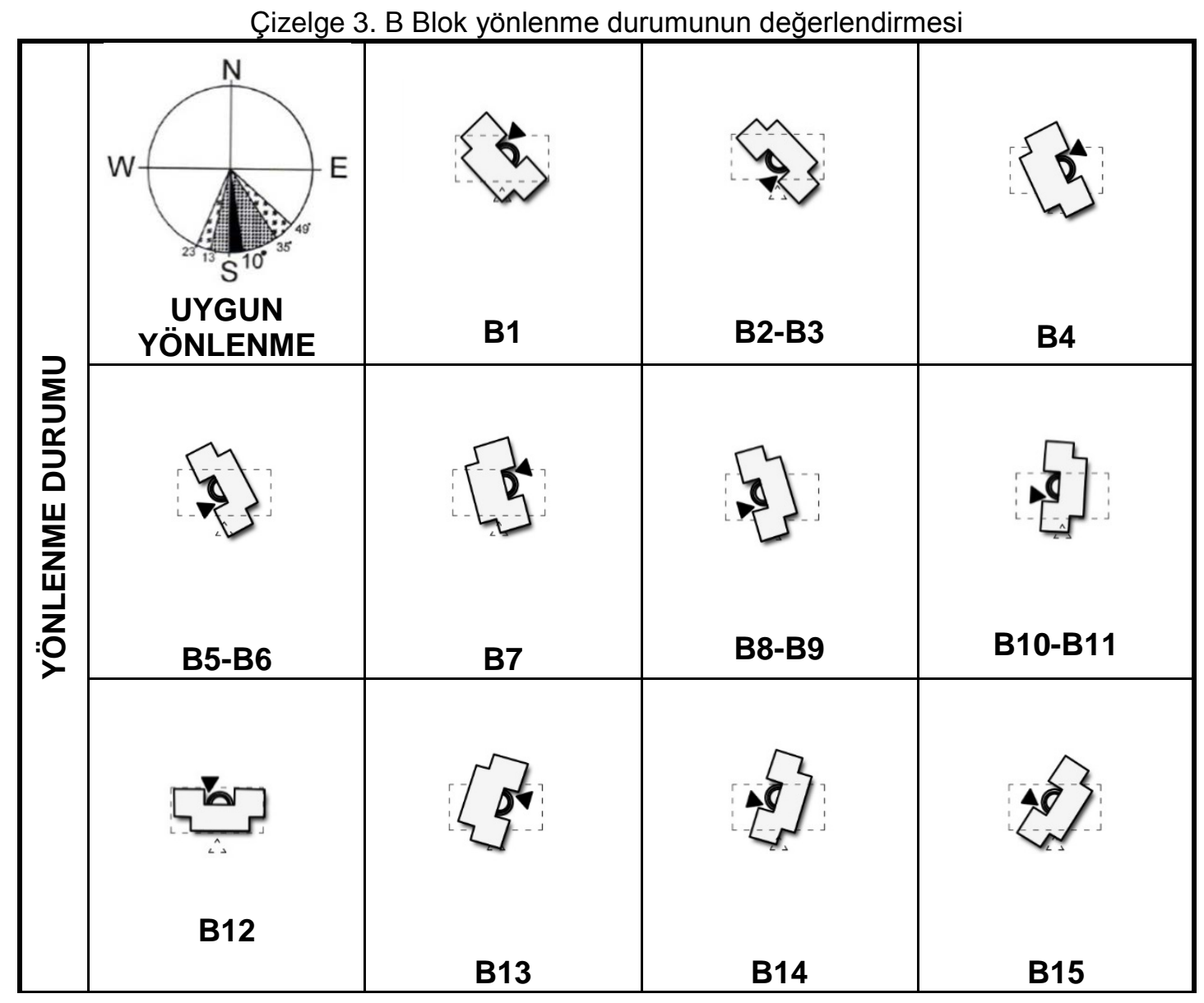

C blok iki girişli olarak düzenlenmiş $L$ formlu bir plan şemasına sahiptir. $L$ formunun uzun kenar doğrultusunun güneyle yaptığı açı değerlendirildiğinde C1 Bloğu $45^{\circ}$ Güneybatı, C2-C3 Blokları 63 Güneybatı, C4 Bloğu Doğu- Batı, C5 Bloğu 56 Güneydoğu, C6 Bloğu $38^{\circ}$ Güneybatı yönünde konumlanmış olup yönlenmenin optimum değerlerini karşılayamadığı görülmektedir. C2-C3 bloğu $29^{\circ}$ Güneydoğu yönünde kısa kenar doğrultusunda uygun yönlenmeye sahiptir. C4 bloğu kısa kenar güney yöne konumlanmıştır. (Çizelge 4)

Çizelge 4. C Blok yönlenme durumunun değerlendirmesi 


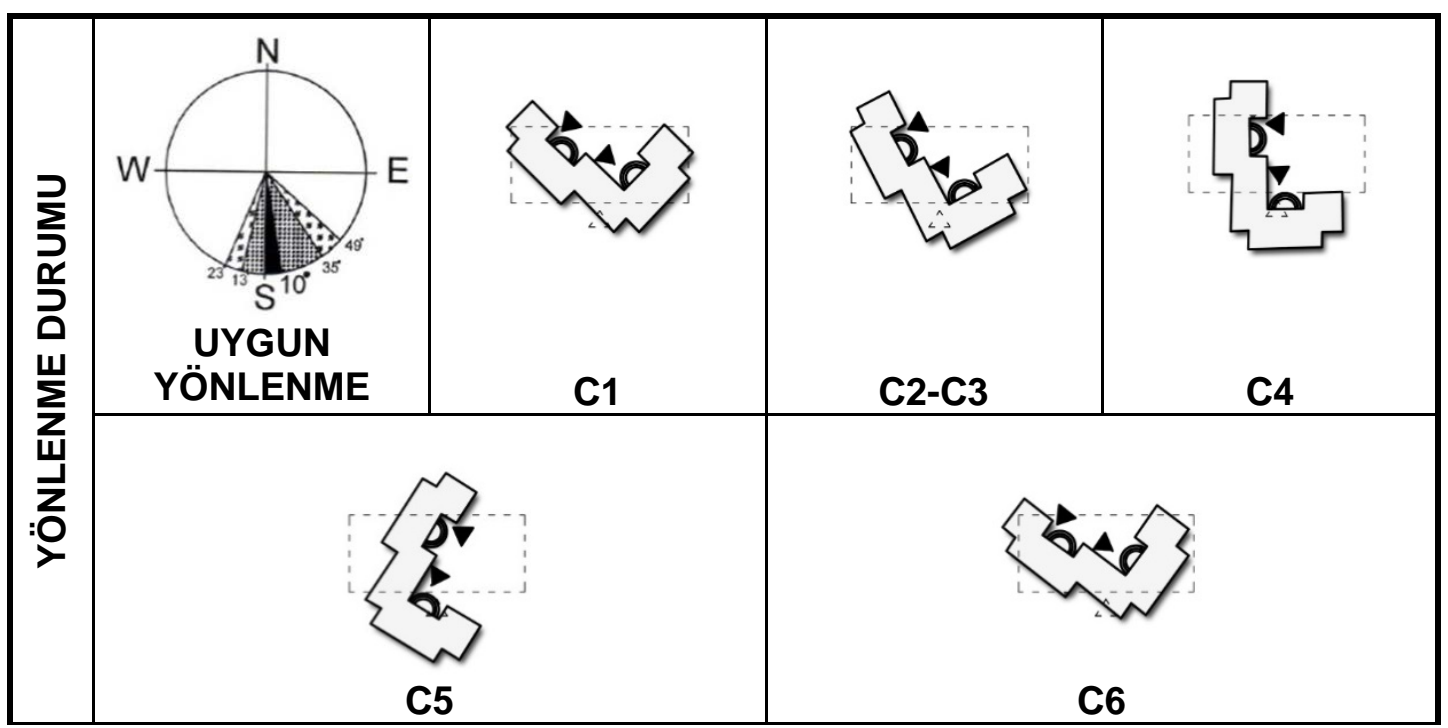

Binevler yapı kooperatifinin tüm bloklarının yönlenme durumlarına bakıldığında $A$ bloğun \%42'si, B bloğun \%93'ü C bloğun ise \%100'ü uygun yönlenme durumu göstermemektedir. Bu durumda tüm yapıların sadece \%30'unun uygun yönde konumlandığı tespit edilmiştir. (Şekil 7)

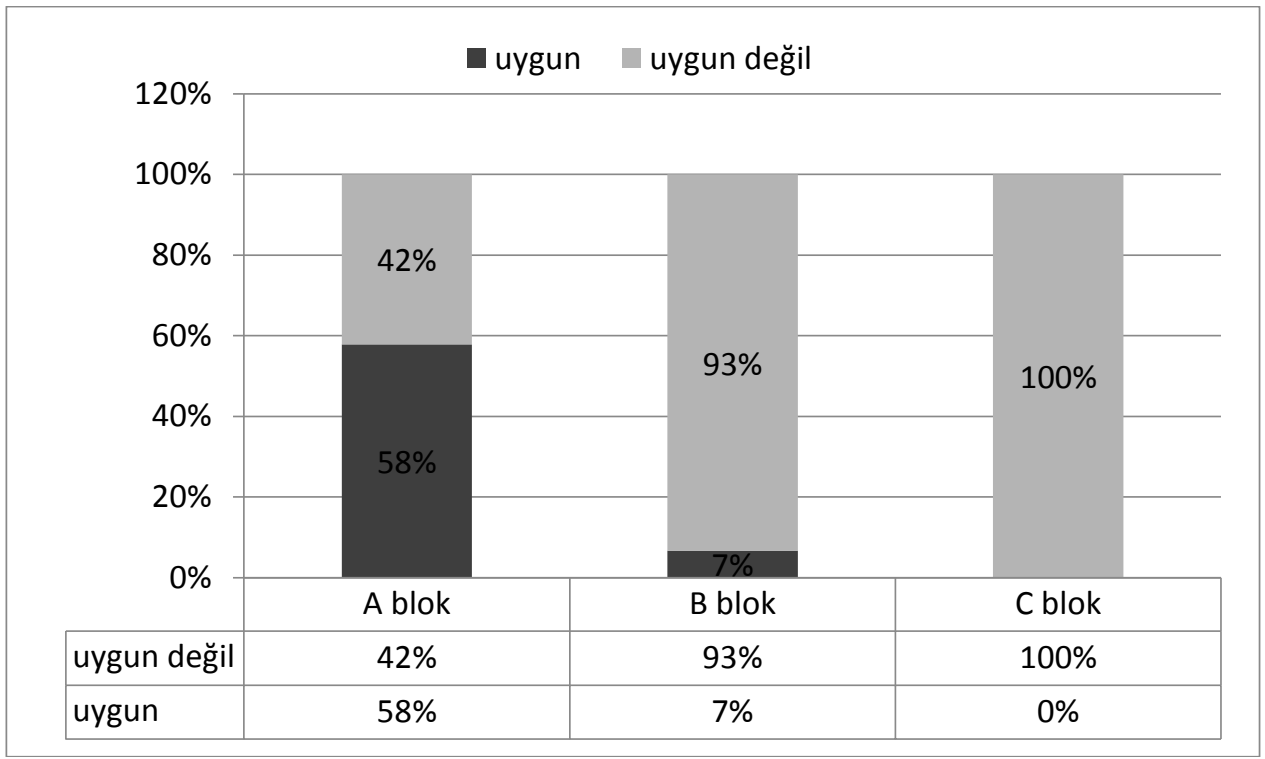

Şekil 7. Blokların yönlenme durumu

FORM: Ilıman nemli iklim bölgesinde yer alan örneklem alanı için serbest bina formları ve Doğu-Batı doğrultusunda 1/1,6 oranında optimum konfor durumunu sağladığı önerilmektedir. Binevler yapı kooperatifinde üç ayrı bloğun form oranları Tablo 5 'de görülmektedir. Bina formlarına bakıldığında asal geometrisi $A$ ve $B$ blokta dikdörtgen $C$ blokta ise $\mathrm{L}$ formunda olup serbest girinti çıkıntıları bulunmaktadır. Tüm blokların boyutsal oranları optimum değerden oldukça fazladır. $\mathrm{Bu}$ durumda kompakt biçimlenişten uzaklaşıldığı için ısı kaybı açısından olumsuzdur. 


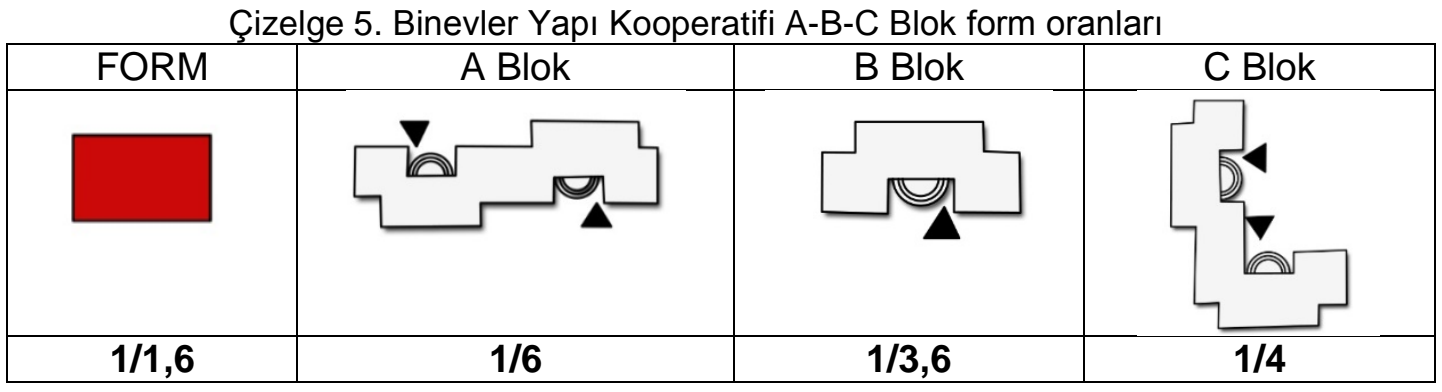

YAPI KABUĞU: Binevler Yapı Kooperatifi betonarme iskelet sistemde inşa edilmiş, duvar bileşeni olarak $19 \mathrm{~cm}$ kalınlığında tuğla kullanılmıştır. Duvar katmanı yalıtımsız sıvalı yalın duvardır. Doluluk boşluk oranı tüm bloklarda yaklaşık \%11 olarak hesaplanmıştır. Döşeme tipi olarak betonarme plak döşeme görülürken binaların bodrum katı olmamakla birlikte zemin üstü $50 \mathrm{~cm}$ subasman mesafesi bırakılarak inşa edilmiştir. Binalarda ısı ve su yalıtımı ile ilgili önlemlerin düşünülmediği görülmüştür. Bazı bloklarda dışarıdan ısı yalıtım katmanı eklenmiştir. Çatı biçimlenişi ahşap konstrüksiyonlu kiremit kaplamalı kırma çatı olup soğuk çatı özelliği göstermektedir. Mevcut durumda yapı kabuğunda önemli derecede ısısal kayıplar olduğu anlaşılmaktadır.

YAKIN CEVRE YAPILASMA DURUMU: Yapıların birbirlerine göre konumları gün ışığından faydalanmasını sağlayacak şekilde planlanmalıdır. Ilıman nemli iklimde yapılar arasındaki mesafe $2 \mathrm{H}-3 \mathrm{H}$ olarak önerilmektedir. Güneş ışınlarının geliş doğrultusu (azimut açısı) ve yatay düzlemle yaptığı açı (yükseklik açısı) dereceleri hesaplanarak binaların güneşlenme durumları analiz edilir. Edirne il merkezinde yer alan çalışma alanı 41,6594 enlem ve 26,5904 boylamlarında konumlanmış olup rakımı 41 m'dir. Ortalama güneşlenme süresi yaz dönemi 2,6 saat, kış dönemi 9,57 saattir (Anonim 1). Çizelge 6'da çalışma alanının yaz ve kış koşullarında günün farklı saatlerinde konuma bağlı olarak hesaplanan güneş açıları görülmektedir (Anonim 2).

Çizelge 6. Çalışma Alanı Güneş Açıları

\begin{tabular}{|c|c|c|c|c|}
\hline & \multicolumn{2}{|c|}{ 21 Aralık } & \multicolumn{2}{c|}{ 21 Haziran } \\
\hline Saat & $\begin{array}{l}\text { Yükseklik } \\
\text { açısı }\left({ }^{0}\right)\end{array}$ & $\begin{array}{l}\text { Azimut } \\
\text { açısı }\left({ }^{0}\right)\end{array}$ & $\begin{array}{l}\text { Yükseklik } \\
\text { açısı }\left({ }^{0}\right)\end{array}$ & $\begin{array}{l}\text { Azimut } \\
\text { açıs }\left({ }^{(}\right)\end{array}$ \\
\hline $08: 00$ & $-7,05$ & 115,32 & 23,41 & 78,73 \\
\hline $10: 00$ & 11,31 & 136,00 & 45,68 & 98,56 \\
\hline $12: 00$ & 22,85 & 162,12 & 65,93 & 133,33 \\
\hline $14: 00$ & 23,99 & 192,07 & 69,55 & 210,43 \\
\hline $16: 00$ & 14,24 & 219,30 & 51,34 & 254,94 \\
\hline maksimum & 24,94 & 180,79 & 71,78 & 179,63 \\
\hline
\end{tabular}

Binevler yapı kooperatifinde yapıların kendi içinde birbirleri ile olan mesafelerine bakıldığında B tipi yapı bloklarının birbirine yakın olduğu $(6 \mathrm{~m})$ görülmektedir. B tipi ve C tipinin karşılıklı çözüldüğü planda ise yine yakın olduğu $(6 \mathrm{~m})$ görülmektedir. A tipi ile B tipi yapı blokların birbirine min. $8 \mathrm{~m}$. uzaklıktadır. A tipi ile C tipi arasında $7.5 \mathrm{~m}$. mesafe olduğu görülmektedir. Dolayısıyla blokların birbirine yakın konumlandığı durumlarda $\mathrm{H}$ mesafesi açısından ılıman nemli iklim bölgesi için önerilen mesafelerin sağlanamadığı görülmektedir. Ayrıca blokların birbirine yakın olduğu durumlarda bina cephelerinin gölge durumları yaz ve kış koşullarında, güneş yükseklik açısına göre 
kesit düzleminde analiz edilmiştir. 21 Haziran ve 21 Aralık tarihleri yaz ve kış dönemlerini temsilen seçilmiştir. Kış dönemi güneş açıları ortalama 2,6 saatlik güneşlenme periyodunda ortalama $23^{\circ}$ yükseklik açısı oluşturmaktadır. Bu durumda komşu blokların cephelerinin tamamına yakınını gölgede bırakmakta ve yetersiz güneşlenme durumu oluşmasına neden olmaktadır. Yaz dönemi güneşlenme periyodu ortalama 9,57 saat olup kesit düzlemindeki birbirine yakın bloklara bakıldığında cephe yüzeylerinde sadece sabah saatlerinde yaklaşık 2 saatlik bir gölgeleme oluşturduğu daha sonraki saatlerde ise sadece yatay düzleme gölge düştüğü görülmektedir. Ancak yaz konforu açısından özellikle yaprak döken ağaçlar, çam ağaçları ve kentsel ısı adası etkisini azaltacak çimen kaplı yüzeyler gibi peyzaj öğelerinin olumlu etkisinin olduğu söylenebilir (Şekil 8-9).
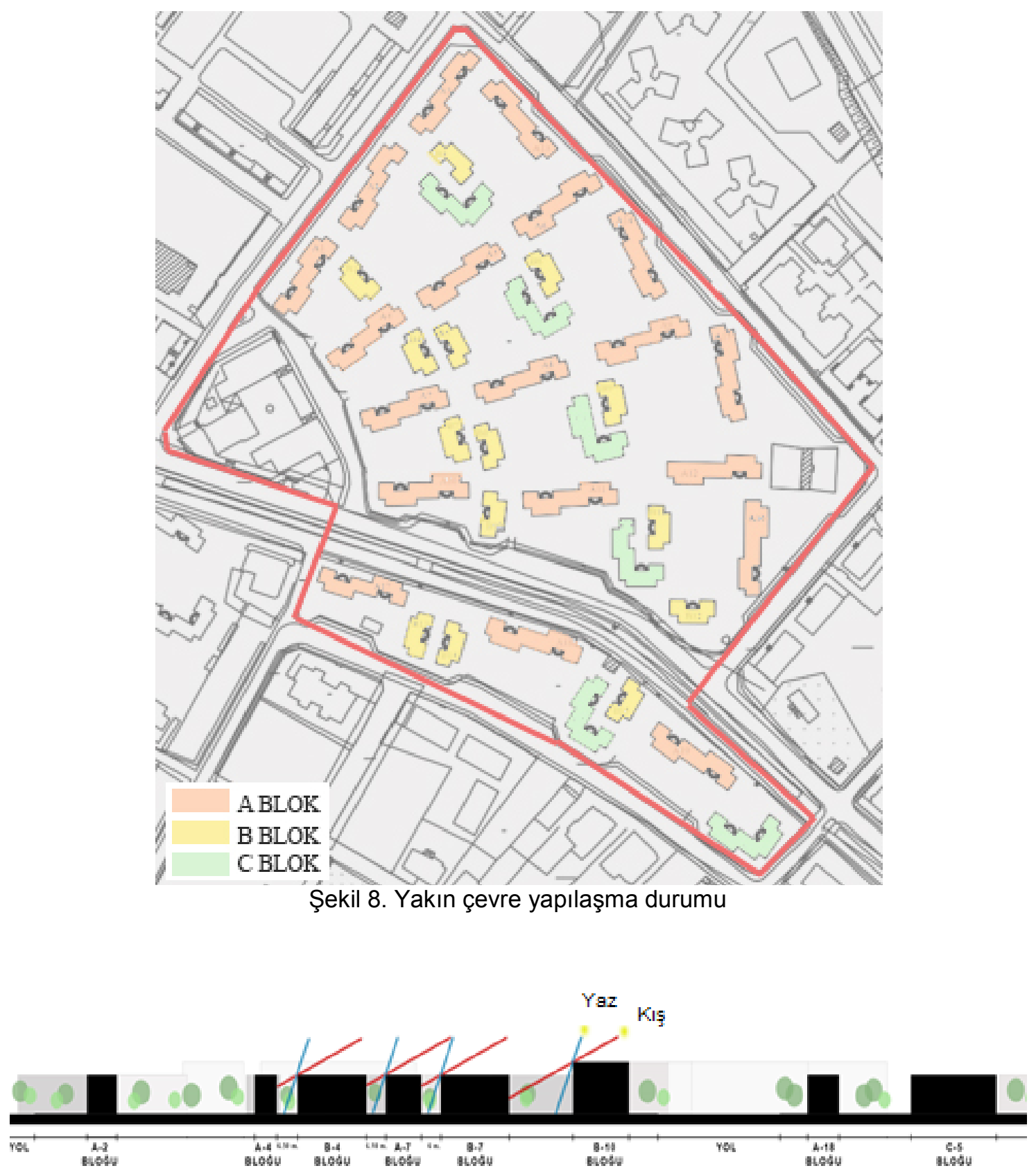

Şekil 9. Binevler Yapı Kooperatifi gölge analizi 


\section{SONUÇ}

Günümüzde çevre ve enerji problemlerinin çözümünde çağdaş bir yaklaşım olarak sürdürülebilirlik ön plana çıkmaktadır. İklimsel tasarım, mimarın en önemli görevlerinden biri olan enerji etkin sürdürülebilir çevrenin sağlanması sürecinin temelini oluşturmaktadır. Avrupa'da iklimle dengeli tasarlanmış bir yapının ısıtılması için tüketilen enerjinin, bölgenin iklim özellikleri dikkate alınmadan tasarlanan yapılarla karşılaştırması yapıldığında, enerji tüketiminin 10 kat daha az olduğu öne sürülmektedir (Spagnolo ve Dear, 2003). Enerji harcamalarında oldukça önemli bir paya sahip olan yapıların tasarım aşamasında alınacak kararlar ile sürdürülebilir yapılar olarak tasarlanması hedeflenmelidir. Bu bağlamda, iklimsel konfor koşullarının sağlandığı tasarım parametrelerinin benimsenerek, yapının konumu, yönlendirilişi, biçimi, kabuğu ve yakın çevre yapılaşma koşullarıyla uygun seçeneklerin belirlenmesi gerekmektedir.

Ilıman-nemli iklim bölgesinde bulunan "Edirne Binevler (1. Kısım) Yapı Kooperatifi" için her bir parametre değerlendirildiğinde;

- Yapının konumu, bölgenin ılıman-nemli iklim özelliklerine sahip olduğu ve yamaç yerleşim önerisine karşın Edirne Binevler Yapı Kooperatifi düz bir arazide konumlanmıştır. Ancak Edirne il merkezinin genel olarak topoğrafyasının düze yakın eğimlerde olması nedeniyle yer seçiminde alternatif bir durum söz konusu değildir.

- İncelenen 40 yapı bloğu 3 tipten oluşmaktadır (A Tipi, B Tipi, C Tipi). A tipi blokların yönlenmelerine bakıldığında, 8 bloğun uygun yönde planlanmadığı 11 bloğun ise kabul edilebilir yönlenme sınırları içerisinde yer aldığı görülmektedir. 15 bloktan oluşan B blokta ise sadece 1 bloğun kabul edilebilir yönlenme sınırları içinde yer aldığı diğerlerinin uygun olmadığı tespit edilmiştir. C blok $L$ formunda yapı biçimlenişine sahip olup değerlendirmeler uzun kenar doğrultusunda yapıldığında tamamının kabul edilebilir yönlenme sınırlarına uygun olmadığı görülmektedir. Ancak 3 bloğun sadece kısa kenarı uygun yönelime sahiptir. Yapılarının tamamı değerlendirildiğinde \%70 inin uygun yönlenme durumu göstermediği tespit edilmiştir.

Ayrıca işlevsel olarak da yönlenme durumu değerlendirildiğinde plan tipolojisi açısından tüm bloklarda ters yönde bir simetri görülmektedir. Bu durum mekânların yönlenmesi açısından değerlendirildiğinde her birimin farklı yönlenme durumlarına sahip olduğu söylenebilir. Bazı konutlarda salon ve mutfak kuzeybatı yönünde konumlanırken bazılarında ise güneydoğu yönünde olduğu ve her konutta farklılık gösterdiği görülmektedir. Bu durumda bir konut biriminde mekânsal yönelim doğru ise diğer konut biriminde tam ters etki yaratmaktadır. $\mathrm{Bu}$ durum planlamada en temel problemlerden biri olarak görülmektedir.

- Yapının formu parametresinde, form oranlarının idealden oldukça farklı olduğu ve bu durumun ısı kayıpları açısından önemli olumsuzluk oluşturduğu tespit edilmiştir.

- Yapı kabuğu parametresinde, duvar yüzeylerinde açık ve orta tonlu renk kullanımı, eğimli soğuk çatı kullanması iklime uygun bir seçimlerdir. Pencere alanlarının toplam duvar alanlarına oranı oldukça azdır (\%11). Bu durum ısı kaybı açısından olumlu görülürken güneş enerjisi kazanımı, iç mekân aydınlık 
düzeyi açısından olumsuzluk teşkil etmektedir. Pencerelerde yaz konforu açısından herhangi bir gölgeleme elemanı bulunmamaktadır ancak yakın çevrede yer alan yeşil doku doğal bir gölge yaratmaktadır. Ayrıca neredeyse yapıların tamamına yakınında balkonların camekânla kapalı bir hacme dönüştürüldüğü görülmektedir. Bu mekân bir tampon bölge oluşturarak kış konforunda olumlu bir etki yaratabileceği ancak yaz koşullarında açılabilecek nitelikte planlanması gerektiği söylenebilir. Yapı kabuğunun ısıtma önceliğine bakıldığında bazı yapı bloklarında mantolama yapıldığı görüşmeler sonucu öğrenilmiştir. Dolayısıyla yapı kabuğu parametresi için yetersiz düzeyde olarak değerlendirilmiştir.

- Yapının yakın çevredeki yapılaşma düzeniyle ilişkisi parametresinde, yapı yoğunluğu açısından yaklaşık \%29 gibi orana sahip olan çalışma alanı yeşil alan kullanımına olanak tanımakta ancak çoğunlukla pasif yeşil ve bakımsızlığı dikkat çekmektedir. Blokların birbirlerine olan mesafelerinde ise bazı blokların çok yakın konumlanması nedeniyle hem yaz hem de kış konforu ve enerji verimliliği açısından olumsuz durumlar oluşmaktadır. Yaz konforunda peyzaj öğeleri ile gölgeli alanlar elde edilebildiği, kış döneminde ise yapı cephe yüzeylerinin büyük bir kısmının güneşlenme durumunun yetersiz olduğu görülmüştür.

1980 yılında yapılan Edirne Binevler (1. Kısım) Yapı Kooperatifi yapıldığı dönemde kullanıcı intiyaçlarını karşıladığı düşünülse de günümüzde artan konfor gereksinimleri enerji konusundaki farkındalığın artması ile beklentileri karşılayamadığı görülmektedir. Günümüz koşulları değerlendirildiğinde Edirne ilindeki yeni yapılaşmaların yanında konut birimi başına düşen arsa payının oldukça yüksek olduğu, yeşil alan kullanımı ile sosyal yaşama imkan sağladığı bu örnekte gerek binaların eskimesi gerekse rant kaynaklı olarak kullanıcıların tamamına yakınında bir kentsel dönüşüm sürecinin başlaması ve binalarının yenilenmesi gibi beklentiler bulunmaktadır. Ancak böyle bir dönüşüm gerçekleşmesi durumunda iklimle dengeli tasarım parametrelerinin öncelikli girdi olarak kullanıldığı tasarımlarla doğru çözümlere gidilecektir. Bu çalışma ile alana özel eleştirel bir bakış sağlanmak istenmiştir.

Yapılacak olan tüm yapı tiplerinde çevreye duyarlı iklimle dengeli tasarımların yapılması beklenmektedir. Bu bakış açısıyla; kentlerin inşa sürecine yeni bir vizyonla yaklaşılması gerekmektedir. Günümüzde yeni yerleşim alanları doğal kaynakların hızla tüketildiği yerler değil; doğa ile uyumlu ve doğal kaynakların kullanılırken korunduğu ve geliştirilmesinin hedeflendiği yaşanabilir ve yaşatabilir mekânlar olarak düşünülmeli ve tasarlanmalıdır. 


\section{KAYNAKLAR}

Akın, C. T., Yerleşme ve Bina Ölçeğinde İklimle Dengeli Tasarım Kriterlerinin Belirlenmesi, Yapı Fiziği ve Sürdürülebilir Tasarım Kongresi, 4-5 Mart 2010, YTÜ, İstanbul, 2010

Akşit, F., "Türkiye'nin Farklı İklim Bölgelerinde Enerji Etkin Bina ve Yerleşme Birimi Tasarımı", Tasarım Dergisi, Sayı: 157, İstanbul, 2005, s: 124-126

Anonim 1. Meteoroloji Genel Müdürlüğü, Veri Değerlendirme, Resmi İstatistikler https://www.mgm.gov.tr/veridegerlendirme/il-ve-ilceler-istatistik.aspx?m=EDIRNE

Anonim 2. "Earth System Research Laboratories", Solar Geometry Calculator https://www.esrl.noaa.gov/gmd/grad/antuv/SolarCalc.jsp

Bektaş, C. Türkiye'de Toplu Konut Sorununa Bir Yaklaşım Örneği: Edirne S.S. Cumhuriye Mahallesi Araştırma ve Yaklaşımı, Mimarlık Dergisi, 78/3, Ankara, 1978, s:45.

Buğday, H. A., Endüstrileşmiş Toplu Konutta Farklı Kullanıcı Gereksinmelerini Karşılayıcı Çözümler Dogrultusunda Bir Mimari Tasarım Araştırması, Yüksek Lisans Tezi, İ.T.Ü. Fen Bilimleri Enstitüsü, İstanbul, 1991

DPT, VII. Beş Yıllık Kalkınma Planı, Ankara, 2000

Erinç, S., Klimatoloji ve metodları (4. Baskı), Alfa Basım Yayım Dağıtım, İstanbul, 1996

Evans, M., Housing, Climate and Comfort, First Edition, The Architectural Press Limited, London, 1980

Gürsel, T., "İklimin Konut Tasarımına Etkileri”, Trakya Üniversitesi Fen Bil. Enst., Yayınlanmamış Yüksek Lisans Tezi, Edirne, 1991, s: 7-8

İmamoğlu O., İmamoğlu V. İnsan, Evi ve Çevresi: Ankara'da Bir Toplu Konut Araştırması, TC Başbakanlık Toplu Konut İdaresi Başkanlığı Konut Araştırmaları Dizisi 15, 1996

İnce, H. Erdem, N. Bir imar adasındaki binaların oluşturduğu gölgelerin konum bakımından incelenmesi: Trakya Bölgesi örneği, Geomatik Dergisi - 2020; 5(1); 58-71

Karaman, A., "Urban Design Aspects of Turkish Towns", University of Maryland, School of Architecture, Studio Lectures, 1995, s: 25-33

Koçlar Oral, G., Güneş Enerjisi ve Yapı, Diyarch Bülten (Diyarbakır Mimarlar Odası Bülteni), Sayı 1, s.11, Diyarbakır, 2010

Kun, F., Turizm Amaçlı Yapıların İklimle Dengeli Tasarımı Kapsamında Soğutma Yükü açısından Değerlendirilmesi (Kuşadası Örneği), Yüksek Lisans Tezi, YTÜ Fen Bilimleri Enstitüsü, İstanbul, 2005

Olgyay, V., Design with Climate: Bioclimatic Approach to Architectural Regionalism, Princeton: Princeton University Press., 1962 
Onions, C., The shorter Oxfort English Dictonary, Oxford: Clarendan Press.,1964

Orhon, İ., Küçükdoğu, M. Ş., Ok, V., "Doğal İklimlendirme", Toplu Konut İşletmesi, Proje Planlama Tasarım El Kitabı, TUBITAK YAE, Yayın No: U.9, Ankara, 1988, s: 122

Royal Jubilee Hospital Patient Care Centre Project, Pacific Green, http://www.viha.ca/nr/rdonlyres/6339cbb7-e799-44fca15da91cddae0c9d/0/7410011 pacificgreendefinedfinal.pdf, British Columbia 2008, (Erişim Tarihi 01.12.2018).

Sev, A., Sürdürülebilir Mimarlık, Yem Yayını, İstanbul, 2009

Spagnolo, J., Dear, R., A Field Study of Thermal Comfort in Outdoor and SemiOutdoor Enviroments in Subtropical Sydney Australia, Building and Environment Cilt 38 (5), Australia, 2003, s. 721-738.

Şenyapılı, T., Ankara Kenti'nde Gecekondu Gelişimi 1923-1960, Batıkent Konut Üretim Yapı Kooperatifler Yayınevi, Ankara, 1985, s:61-63, 94.

Tönük, S. Bina Tasarımında Ekoloji, Yıldız Teknik Üniversitesi Basım-Yayın Merkezi, İstanbul, 2001

Varlı, E., Konut Tasarım Sürecinde Kullanıcı Katılımının Edirne Cumhuriye Mahallesi Örneğinde İncelenmesi, ISCR, Antalya, 2017

Yeang, K., Eko Tasarım, YEM yayınları 193, İstanbul, 2012

Yıldız, E., Bina İçi Çevre Mekânlarının İşlevine ve Bina Kabuğuna Bağı İklimsel Konfor Açısından Yön Seçiminde Bir Yöntem, Doktora Tezi, İTÜ Fen Bilimleri Enstitüsü, İstanbul, 1989

Yılmaz, E. Çiçek, İ., Türkiye Thornthwaite İklim Sınıflandırması. Journal of Human Sciences, 2016, 13(3), 3973-3994.

Yılmaz, Z., Türkiye ve İrlanda Binalarin Enerji Etkin Tasaım ve Yapımı için Sürdürülebilirlik Stratejileri, ITÜ Araştırma Fonu, İstanbul, 2006

Yılmaz, Z., Koçlar Oral, G., Manioğlu, G. Isıtma Enerjisi Tasarrufu Açısından Bina Kabuğu Isı Yalıtım Değerinin Bina Formuna Bağlı Olarak Belirlenmesi, Proje No: 985 Sonuç Raporu, I.T.Ü., İstanbul, 2000

Zeren, L., Mimaride Güneş Kontrolü, İTÜ Yayınları, İstanbul, 1978

Zeren, L., "Mimarlıkta Yapma Çevre Tasarımı ve Güneş Enerjisi", Güneş Enerjisi ve Çevre Dizaynı Ulusal Sempozyumu, İTÜ Mimarlık Fakültesi, İstanbul, 1978

Zeren, L., ve diğerleri, "Türkiye'de Yeni Yerleşmeler ve Binalarda Enerji Tasarrufu Amacıyla Bir Mevzuat Modeli'ne İlişkin Çalışma", Araştırma Projesi, ITÜ, Uyg-Ar Merkezi, İstanbul, 1987

Zorer, G., Yapılarda Isısal Tasarım İlkeleri, YTÜ Mimarlık Fakültesi Baskı İşliği, İstanbul, 1992 